\title{
Acquisition of Talent for Student to Enter the Industry Based on Employer
}

\author{
Amanina binti Muhamad Sanusi, Saifullizam bin Puteh, Nur Farha bte Hassan, Zaiton binti \\ Arifin, Nan Nurul Hidayah binti Megat Salleh
}

\begin{abstract}
Engineering graduates need to be accepted by their employers before they can work in the industry. Employers have to recruit talents for the in industry through interviews. The study was conducted to identify the constraints or problems experienced by the industry with regards to the acceptance of new engineering graduates. The structured partial interviews involved five employers in the electrical, civil, and mechanical engineering fields. Specifically, the interviews revolved around the graduates' abilities needed by the industry, which also helped the graduates secure relevant jobs. The data was then transcripted to identify the constraints and issues in this study. As per the results, the employers highly valued manoeuverability
\end{abstract}

\section{Keywords: Talent, Engineering Student, Employer, Industry}

\section{INTRODUCTION}

Prospective graduates, with cooperation from their institutions, need to learn and apply work-relevant skills so as to attain qualifications required by industry [1]. Employees who are talented and highly skilled can easily perform various types of work productively, apply skills and talents like quality workers, and spur the development of the industry [2]. Graduates with work talent, knowledge, skills, productivity, innovation and technology, intellectual capital, ethics, and morals will be able to surf the global tide of modernity and dynamism [3] [4]. Jobs become difficult to be obtained because of the tall demands of the employers from the employees, in that the latter should have a variety of skills in the relevant field. Likewise, there are among employers who do not want to select employees with high skill requirements and those who will make the graduates will feel bored within short periods [5]. Human talent is considered to be a life skill that make graduates competent in their professional careers [6]. Ergo, the main objective of learning in higher education institutes (HEI) is to create graduates who are skilled and knowledgeable in line with the needs of the industry [7].

Revised Manuscript Received on April 19, 2019.

Amanina binti Muhamad Sanusi, Faculty of Technical and Vocational Education (FTVE), Universiti Tun Hussein Onn Malaysia 86400 Parit Raja, Batu Pahat, Johor, Malaysia.

Saifullizam bin Puteh, Faculty of Technical and Vocational Education (FTVE), Universiti Tun Hussein Onn Malaysia 86400 Parit Raja, Batu Pahat, Johor, Malaysia

Nur Farha bte Hassan, Faculty of Technical and Vocational Education (FTVE), Universiti Tun Hussein Onn Malaysia 86400 Parit Raja, Batu Pahat, Johor, Malaysia

Zaiton binti Arifin, Department of Electrical Engineering, Politeknik Sultan Abdul Halim Mu'adzam Shah Bandar Darulaman, 06000 Jitra, Kedah, Malaysia)

Nan Nurul Hidayah binti Megat Salleh, Faculty of Technical and Vocational Education (FTVE), Universiti Tun Hussein Onn Malaysia 86400 Parit Raja, Batu Pahat, Johor, Malaysia

\section{LITERATURE REVIEW}

Contemporary employers want engineering and technology students who are well-equipped with talent, technical and communication skills, spirituality, teamwork, leadership qualities, lifelong learning attributes, critical thinking and problem-solving abilities, as well as ethics and morality. Such students are capable of using their skills and talents to fit into the current global employment scenario [8]. In addition, employers also have to put up with numerous graduates who lack professional expertise, namely thosewho are less knowledgeable and training-deficient. Simply put, employers require a skilled and talented workforce with high levels of academic and soft skills in the respective professions [5].

Graduates who lack the talent, ability, and experience negatively impacts the national economy because they are not able to provide skilled and semi-skilled manpower to assist in the development of the rapidly-growing country. Youth unemployment and skilled worker shortages will slow down the achievement of a high-income country status [7]. Hence, there is a need to identify the current students' mastery of skills to ascertain the extent of their readiness for employment. Students with work talent are more likely to exhibit good behaviour and mentality, apart from being capable of making decisions and taking action by themselves in accordance with the norms laid down in the chosen career [9] [10]. Therefore, a framework which enhances the work-related skills of engineering and technology students is needed to help equip graduates with the qualities required in the contemporary competitive markets [11].

For freelance work, graduates need to have communication, leadership, and organisational skills, teamwork, cooperation, proactivity, sociability, as well as continuous learning mindsets [12] [13]. Other crucial attributes include diligence, self-motivation, compassion, discipline, enthusiasm, integrity, and work commitment [14].

As per a survey on hiring managers from five Asian countries, 51 percent of them have reported that work it was difficult to recruit employees with sufficient skills and talents [15]. In addition, the skills acquired during education and training did not match the requirements of the jobs, thus further complicating the search for qualified new workers [15]. Some 28 percent of employers have also mentioned that the lack of soft skills among the workers gave rise to

Published By:
Blue Eyes Intelligence Engineering \& Sciences Publication 
International Conference on Recents Advancements in Engineering and Technology (ICRAET-18) |15th and 16th March 2019|Siddhartha Institute of Technology \& Sciences, Telangana, India.

skills mismatch during employment.

\section{METHODOLOGY/MATERIALS}

Interview are a method of data collection in social researches which include the field of education. Interviews are one of the alternative means for the respondents to further reinforce the findings of the study. According to [16], it is possible to obtain accurate information from interviews on a small population. Relevant information needs to be directly obtained by the researchers to determine the domain and talent components required by the employers in the industry. The first step in the process of the interview was to identify the individuals who were involved in the current study. Here, interviews were conducted on five employers who (1) were of electrical, mechanical, and civil engineering backgrounds; (2) had at least five years of experience; and (3) were professionals in the recruitment of new workers. The information of interest comprised the engineering students' skills which were required by the employers, as well as the current issues in the industry.

\section{RESULTS AND FINDINGS}

To explore the problem, interviews have been conducted on employers of electrical, mechanical, and civil engineering backgrounds. Following transcription of the interview data, thematic analysis was performed to identify the components of talent. Knowledge of the same would help students prepare for absorption by the industry after their completion of study.

The qualitative data underwent six steps during the attempt to isolate the the components of talent via thematic analysis [17]. The six steps were as follows:

1. The reviewer read and examined the results of transcript data one by one in accordance with the purposes of the review. The reviewer had to be familiar with the required data and needed to sign the paragraph(s) that were important with regards to the review

2. The reviewer needed to issue the codes which corresponded to the data derived from the results of the interview study of transcripts. The data had to be related to each another with regards to the review

3. The researchers needed to find suitable themes to classify the codes as per the theme of study

4. The researchers had to determine the suitability of the components of the classified themes

5. The researchers needed to describe in detail the purpose of the components and themes with respect to the study.

6. The researchers had to write reports based on the findings of the study.

A total of six themes were produced following document and thematic analyses. The components of talent required by the employers during the hiring of graduates were classified according to the following themes:

Table 4.1: Components of Talent

\begin{tabular}{|c|l|l|l|l|l|l|}
\hline Component & $\begin{array}{c}\text { Sub } \\
\text { component }\end{array}$ & & & & & \\
\hline \multirow{3}{*}{ Relating Talent } & $\mathrm{n}$ Communicatio & & & & & \\
\cline { 2 - 6 } & Empathy & & & & \\
\cline { 2 - 6 } & Harmony & & & & \\
\hline
\end{tabular}

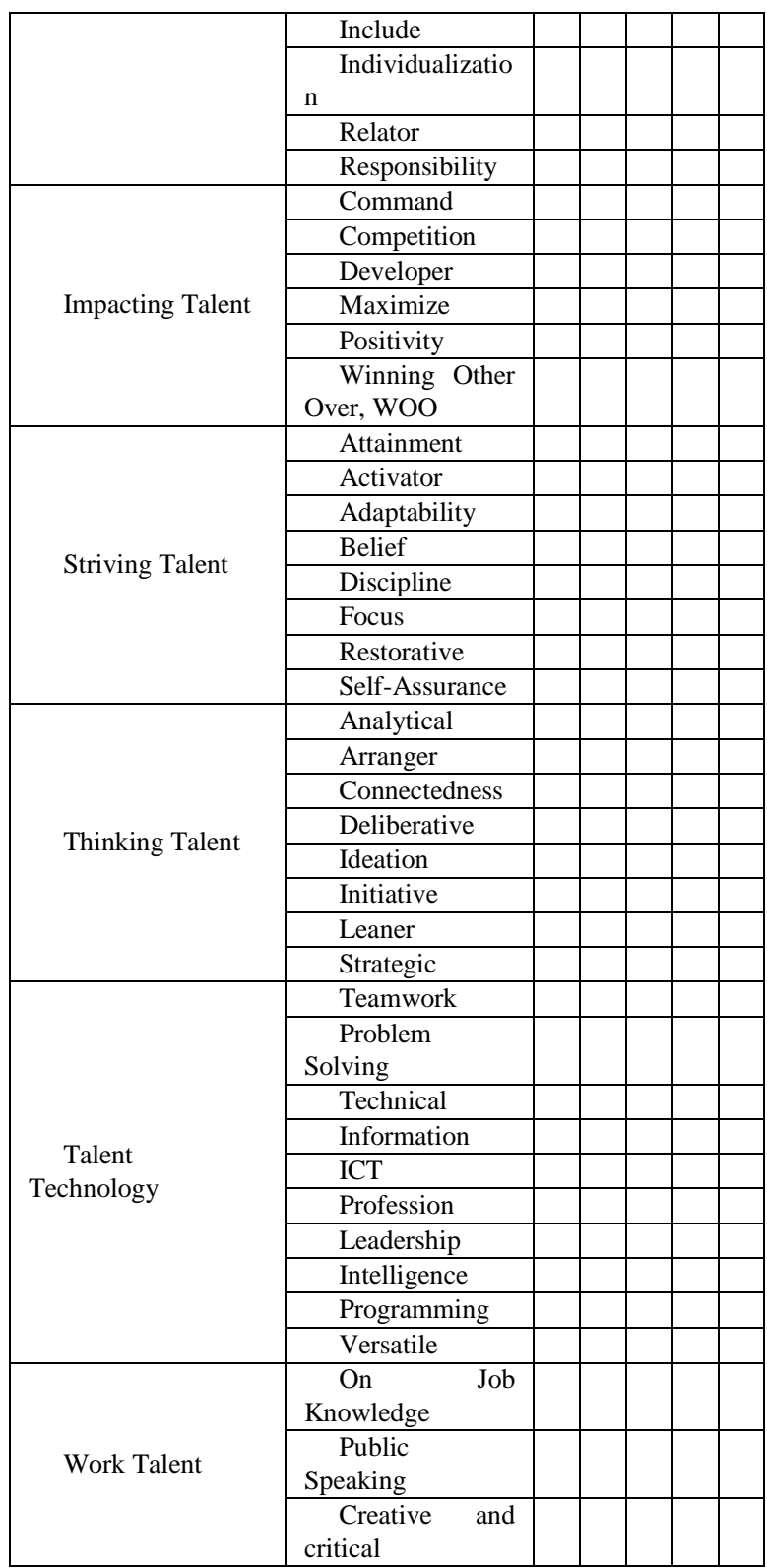

\section{Relating Talents}

According to [18], relating talent were talents that were related to each other. Examples included communication, empathy, harmony, inclusiveness, individualisation, relator, and responsibility.

\section{Communication}

Communication talent occurs when a student is able to explain something in a clear, interesting, and easy-tounderstand manner.

"In my opinion, relating talents are associated with quality students. When we want to interview them, we need communication, so if we can't relate, means that we will be pointing here and there during the interview."

(Participant 1)

"When a person gets employed, hel she has to communicate. That is, when hel she communicates with a superior or colleague, he/ she must also communicate with 
his/ her subordinates. So, it is important to have the ability to communicate."

(Participant 2)

"In this sense, communication means relationships. Relating talents are important. It is easy to work with siblings, friends, best friends,... but what about people from different departments? For example, we need to ask what are our duties and encounters. I think my communicating talent is inadequate. So, for example, when I know, my communicating talent is inadequate, I need to improve. Communication means relationships... relating talents are important so that it becomes easier to work, not only with siblings or best friends, but different people from department different departments as well."

(Participant 3)

"Communication talent in employees is important to ensure the success of a job, which involves customers."

(Participants 4)

"Communication talent is in the industry, so that hel she (a worker) can communicate with those around him/ her."

(Participant 5)

Empathy

Empathy occurs when an individual can feel and understand the emotions of others without anyone explaining the same to them.

"Among the people we want to work with, we need empathy, which is a sort of sixth sense.

(Participant 1)

"If a person is empathetic, there will be harmony. Empathy is invisible, but may still be seen in people's faces."

(Participant 3)

"Hel she (a worker) requires empathy... to take on more tasks given to him/ her. For example, if hel she is in the Engineering Division, hel she should know what hel she needs to do for the customers or end users."

(Participant 5)

\section{Harmony}

Harmony arises when an individual is capable of cooperating and reconciliating. They do not like to create disputes, and will attempt to stop such events.

"in the short term, creating a fun and harmonious workplace will give us teamwork."

\section{(Participant 1)}

"Harmony is important so that we can maintain the work environment in good condition... because we need people who do not give rise to problems, be it from his/ her actions, or language."

(Participant 2)

"Being sociable,... hel she can easily mix and work together with his/ her colleagues."

(Participant 5)

\section{Inclusiveness}

When an individual appreciates another person, and is able to deal with all of types of people as well as give credit to all key persons in a group, inclusiveness will result.

"In the people we want to work with, we want to see empathy. Empathy is like a sixth sense... same goes for harmony, acceptance, individuals, friends, responsibility."

(Participant 1)

"Examples of talents include communication, empathy, harmony, and acceptance."

(Participant 5)

\section{Individualisation}

An individual's talent is manifested when he/ she is able to see the styles, motivation, and methods by which other people think, as well as establish friendships.

"Individuals, friends, are responsible." (Participant 1)

"It will give rise to an individual who is more likely to secure employment."

(Participant 2

"Other than the, individualisation talent is very important"

(Participant 3)

"Mutually, closely, also to an individual.” (Participant 5)

\section{Relator}

Here, an individual strives to be more friendly and familiar with individuals with whom he/ she is already familiar.

"Individual, friendly, responsible." (Participant 1)

"When an individual accepts another individual, hel she welcomes talent."

(Participant 3)

"(It is related to) friendliness with fellow colleagues, who may be responsible for doing the work of (the individuial)."

(Participant 5)

\section{Responsibility}

This term describes an individual who is ready to accept any task and work on it under full trust.

"When you are responsible, you will secure a job." (Participant 1)

"With good attitudes, an employee can head anywhere and work on anything. Hel she can show people good values, because the interest is there, the focus is there,... because hel she has the the responsibility. "(Participant 2)

"The advantage of an extraordinary person is that the interviewers will remember (him/ her). Later, we will discuss again,... we will see what hel she got is made up of. We as Muslims have to show... our responsibility. As Muslims, (we should) appreciate (people from) other religions similarly. I was in an interview with this company... the Chinese even wanted to see whether we Muslims performed our prayers or not." (Participant 3)

"All of us want to work enjoyable, right? More so with responsibilities responsible people."

(Participant 5)

\section{Impacting Talents}

According to [18], impacting talents can influence or convince others and push oneself to be more productive or strive towards perfection. Such talents can be classified into six, namely command, competition, developer, maximising, positivity, and winning over others.

"To be a good leader, (an individual) must have the talent to influence... how to convince or assure your client or boss that your decision is correct."

(Participant 1)

"Engineering disciplines require an engineer to make decisions, so hel she should have the talents to influence the decision-making process in order to be accepted by others, be it superiors or any other person on duty." (Participant 2)

"Talent means... the ability to influence the people who want the project, like the tendere. The head of the team 
needs to be a talented leader... to make the subordinates want to do something. Talent affects self-motivation and the thought process. When a person has to lead a team,... hel she needs to win over others right. Hel she can influence others to do the correct things."

(Participant 3)

\section{Command}

It refers to the ability to take over a piece of work and direct other employees to do it according to the correct specifications without fear of dealing with other employees.

"When we interview a graduate, we will see the way hel she communicates, the way he/ she relates with us... (we see) how how hel she solves problems in a group. From there, we will know whether hel she has motivation and command talent."

(Participant 1)

"Regarding the appropriate components of influence,... we need people with maximum talent who always do their best. It is not difficult to lead such people,... usually they will listen to instructions if we are already doing so."

(Participant 2)

"Autocracy is the right for a dictator. The dictator may lead rightly or wrongly. This type (of leadership) is for a bygone era. Now, we cannot lead blindly,... the difference between a dictator and a person with directing talent is that (the latter) can thank clearly and focus on the aspects that matter."

(Participant 3)

"In my view, an appropriate talent is the talent to command."

(Participant 4)

"In the working world, when a person is given the responsibility,... especially when he/ she is holding a high post, hel she will automatically have subordinates... it is important that he/ she can influence the staff under him/ her to do the job the right way."

(Participant 5)

\section{Competition}

Competition talents encompass a sporting spirit and the desire to win a healthy competition or be the best.

"For me, you need competition to become a better engineer. You need talent, self-motivation, motivation, and interest. With interest, we can improve our motivation to a adapt to the workplace."

(Participant 1)

"...the talent to lead, match, develop, maximise, be positive, and win others over." (Participant 2)

"In my view, appropriate talent... the talent to command and compete... (are important)." (Participant 4)

"With impacting talent, he/ she can lead, match, develop, and maximise wotk output."

(Participant 5)

\section{Developer}

Developing talent occurs when an individual identifies the abilities of other employees and helps them hone the same without arrogance and egoism.

"For me, talent lies in the development of talent."

(Participant 1)

"In terms of talents,... there is a responsibility to rival the qualities of other people, there are elements of potential, there are elements of giving. People believe something or someone so that he can receive (the benefits)."

(Participant 2)

"Building talent, honing maximum talent, winning others over."

(Participant 3)
"Aptitude, competition, command, positivity, and talent developers." (Participant 4)

"We need to build talent ... for work experience."

(Participant 5)

\section{Maximising}

Maximising talent refers to a push for someone to be better, and the strength to be the best.

"After she improved her knowledge and proficiency, she climbed the career ladder. We need maximum talent to always generate high-quality works." (Participant 2)

"Building talent, honing maximum talent, winning others over."

(Participant 3)

"Aptitude, competition, command, positivity, and talent developers."

(Participant 4)

"When hel she has this talent, he/ she can influence his/ her subordinates to lead, improve, and maximise their talents"

(Participant 5)

\section{Positivity}

It refers to the ability to make others enthusiastic and friendly. This requires modesty and positive attitudes improve the confidence of others.

"We need positive talent, the talent to win others over... we need to be aware of our weaknesses, drive ourselves, and compete so as to get promoted... so that you will not be sitting at one place or standing alone (i.e. not improving)."

(Participant 1)

"A person who benefits (the organisation) will be followed by other. Leadership by example is sometimes difficult when we have to obey instructions... maybe you will need 3 to 5 years to improve on this skill to the maximum... to always be positive and win others over."

(Participant 2)

"Employers always like to see positive people even though the situation may be negative... (employers especially like those who) can convert a negative situation to a positive one."

(Participant 3)

"In my view, appropriate talent... the talent to command, compete, develop, and be positive (are important)."

(Participant 4)

"If we are positive, we will lead,... we will use that talent
to create a positive situation."

\section{WOO (Winning Others Over)}

Talent wins others over by expressing the desire to work in earnest, wishing new colleagues well, and discussing with them the things in common.

"In winning over others, we compete with others to advance ourselves, not compete for things that may or may not be right. Indeed, if an individual has this talent, hel she will be easily accepted for work."

(Participant 1) 
"It takes 3 to 5 years to maximise one's skills... to always be positive, matching, and winning over others."

(Participants 2)

"If you want to win others over, you have to think how you want to do it, how you want to make it happen. If it is not right, (we have to think) how we can recommend it so that everyone likes it."

(Participant 3)

"In my view, appropriate talent... the talent to command, compete, develop, and be positive (are important) to win others over."

(Participant 4)

"The ability to win others over means that (the worker) is very good. Everyone needs to have this talent, and it should be applied to all levels of (the organisation). All of us want to work enjoyably... so, responsibility and the ability to win others over are a must."

(Participant 5)

\section{Striving Talents}

According to [18], self-motivation refers to the personal drive to succeed or achieve something. It is usually divided into three, namely external and internal motivation, as well as self-regulation [19].

"When working, we have a target... we need motivation to achieve our targets."

(Participant 1)

"Self-motivation is relevant to the employement of talented candidates... we see when they are alone, how do they balance the motivational components so that they can reality, they should not just produce quality work, but have a quality life as well."

(Participant 2)

"Self-motivation is very important in a person... because it complements his/ her talents. When they have motivation, they will also have the passion to aim higher."

\section{(Participant 3)}

"Striving talents... and self-motivation... are actually beneficial for ourselves and the graduates." (Participant 5)

\section{Attainment}

This attribute is manifested when an individual works hard to achieve the targets.

"A person can always ask for support from the staff or bosses boss to achieve (his/ her goals).”

(Participant 1)

"They need to constantly upgrade their skills. These skills, when accumulated, will defenitely land fresh grads in employment."

(Participant 2)

"Targets enable us to go anywhere or achieve anything in our lives."

(Participant 3)

"Amid all talents, one of them concerns the planning and achievement of targets in a given job.” (Participants 4)

"The ability to work hard and achieve targets needs to be present in everyone, not just the graduates. We need to work hard to get something done."

(Participant 5)

During activation, a thought is converted into an action. For example, the decision to keep trying and learning in spite of failure come with the act of striving to succeed.

"(It is about) how you convince or assure your client or boss that your decision is correct... how you influence someone to buy the kinds of goods we sell. When we interview them (the applicants), we also want to influence work efficiently. They need discipline and focus, but in

\section{Activator}

them to be good employees. Your bosses influence you... if your boss is wrong, it will also negatively affect you." (Participant 1)

"We talked about the things which have been settled; we wanted to formalise her Activator (AC), because she had the results of the decision."

(Participant 3

"An activator converts conscious thoughts into actions. For example, they may decide to continue trying even when they have failed. Hard work, good attitudes are important... the same goes for the want to try. Life is full of risks, so we need to take risks, guided by knowledge.” (Participant 5)

\section{Adaptability}

Adaptability concerns the ability to adapt and accept changes without feeling angry or frustrated.

"Having this component (adaptability) will make an individual favourable for employment.” (Participant 2)

"adaptability talent is important needs in work, adaptability just how to manage the srounding when to adapt with many people in same time" (Participant 3)

"It is important for the students and graduates to adjust to the job."

(Participant 5)

Belief

Beliefs are not easily changed. Additionally, success is more than just money and commitment; ethics and of your belief is one of your play a key role as well.

"When the environment is not something you are used to, you will improve yourself... you learn from the situation... it is important to believe as well. To be a good engineer, you need discipline, because constructions also deal with the lives of people."

(Participant 1)

"When a person strives to succeed, he prioritises trust and the decision. From there, remunerations in the form money will come."

(Participant 5)

Discipline

A disciplined inidividual in is always timely and on schedule. He/ she will also ensure that the plans are progressing well.

"When doing work, one needs to be aware, disciplined, and focused. Quality should not just be present in work, but life as well."

(Participant 2)

"discipline is important to achive the goals of inidividual, but they needs to fixed their own discipline, discipline is right way to maintain your own focus to achive your goals, to become a sucess person"

(Participant 3)

"The most important (attribute is) discipline"

(Participant 4)

\section{Focus}

It refers to the ability to always be on track in line with the purpose of life and employment.

"When you focus, you will do whatever it takes to succeed. There is always a purpose in life, so when you have focus and you have a goal, you will achieve the goal." (Participant 1)

\section{Published By:}


"Focus is when we make something work. Focus leads to the best results."

(Participant 2)

"Discipline enables a person to focus on his/ her goals and srive to win."

(Participant 3)

"A focused person is always on track, in line with purpose of life and employment. Graduates should always have a goal... the should want to do various tasks, and need to focus."

(Participant 5)

\section{Restorative}

A person with this attribute is capable of converting his/ her talent back to its original state if it is not needed. Such individuals will usually be able to act and improve the situation.

"Regarding our jobs, we should be like troubleshooting machines."

(Participant 4)

"During restoration, we return something to its original condition. For example, when a person is given the task of supervising a project, things on site may not happen as planned. These things always occur. So, the supervisor should always think of ways to rectify such issues."

(Participant 5)

\section{Self-assurance}

Self-confidence concerns the ability to make the correct decisions and stand by them. Individuals with this attribute will like to hear and be heard as well as appreciated because they have the inner strength. They usually do not like to mix with people who are considered to be "not important".

"Talents need to be repeatedly polished. During my university years, we have been exposed to on-site jobs via factory visits, for example. I began to think how I could secure a job, and from there, I prepared myself by studying more, talking with engineers, and even and even in our professional careear in teaching of class use technology. To get our work done properly and win over anyone, we need to have talents."

(Participant 1)

"We want to see graduates who are able to clearly describe the issues or situations. From there, we can see how confident he/ she is."

(Participant 3)

"Talents are necessary to increase one's self-confidence when taking on a job."

(Participant 4)

"Graduates need to be able to solve problems, apart from having self-esteem and talent."

(Participant 5)

\section{Thinking Talents}

Thinking talents, according to [18], affect the ways by which humans collect and process information.

"Analytical engineering has became a very important field. We need to analyse situations in order to generate the best results at every stage."

(Participant 2)

"The most important arrtibute for me is the ability to think. Employees with this ability can manage day-to-day tasks and successfully carry out missions."

$$
\text { (Participant 3) }
$$

"In my current field, thinking is of utmost importance in the management of a project."

(Participant 4)

"For graduates thinking talents are indeed necessary because, with that, they can collect, process, and make decisions based on the information or even mental pictures."

(Participant 5)

\section{Analytical}

The talent refers to the ability to find the reason for an occurrence.

"Once you have analytical talent and study the course you want, you can secure a job, provided that you have the degree. However, if you have any degree but are not a natural talker, it is not that good. If you have a degree but do not know how to control people, it is also not good. So, I dare say talent is number one and tbhis should be supported by other qualities."

(Participant 1)

"(A person with analytical talent can) analyse the situation and determine what is needed with trust and fairness." (Participant 3)

"When an unexpected problem occurs in a project, the workers should try to salvage the project. Yes, if there is a sudden problem, then they should think about how to resolve $i t, \ldots$ whether to continue or change the current approach. They need to do this fast too."

(Participant 5)

\section{Arranger}

This talent refers to the ability to handle something - an important quality of a supervisor.

"You need to think and learn... it does not matter if you are a graduate or otherwise,... as long as you are an engineer, you will need to think in terms of a coordinator and be trustable."

(Participant 1)

"Analyse the situation and coordinate accordingly,... correct and fair decisions will make you trusted."

\section{(Participant 3)}

"A coordinator needs to do the job of a supervisor and manage. Hence, for a graduate to become a coordinator, hel she will require considerable experience and knowledge."

(Participant 5)

\section{Connectedness}

Connectedness occurs when there are two different groups, and when one group is able to give impetus to the other group's members to succeed.

"You need to think and learn... it does not matter if you are a graduate or otherwise,... as long as you are an engineer, you will need to think in terms of a coordinator and be trustable."

(Participant 1)

"Connectedness occurs when there are two different groups,... when the leader of one group can help the other group's members to succeed."

(Participant 5

\section{Deliberative}

Deliberation takes place when a matter is dealt with carefully and a decision is not made in a hurry.

"For example, if I make decision A, what will happen... if I make decision $B$, what will happen. So, I will need to come to a decision cautiously after assessing all the risks and benefits."

(Participant 5 ) 


\section{Ideation}

Ideation refers to the talent in producing ideas, brainstorming, and thinking highly of the group.

"For me, the talent that matters is the generation of ideas."

(Participant 1)

"First of all, there must be an analytical component, followed by coordination and ideation. Sometimes, we also need strategies to perform and organise our work." (Participant 2)

"Brainstorming and generation of ideas are the qualities of a manager... we have had graduates like this." (Participant 5)

\section{Initiative}

Initiative concerns the ongoing eagerness to understand all facets of one's work.

"(Initiative refers to the) desire to know all aspects of the work on an ongoing basis."

(Participant 5)

\section{Learner}

Learners arise what an individual is interested to learn new things in different areas.

"You need to think and learn... it does not matter if you are a graduate or otherwise,... as long as you are an engineer, you will need to think in terms of a coordinator and be trustable."

(Participant 1)

"I'm always learning, and I love to read something repeatly."

(Participant 5)

\section{Strategic}

With strategic talent, an individual will be able to apply past experiences in various scenarios and find ways to settle matters[18].

"In my view, I am strategic."

(Participant 4)

"Practice lessons and past work experience improve one's (strategic talent)."

(Participant 5)

"Strategic students are able to apply existing experiences in various scenarios and settle matters."

(Participant 5)

\section{Technological Talents}

Technological talents are derived from the learning outcomes of technology so that they can be used during work [20]. The aspects of technological talents include knowledge, proficiency, practicality, and analysis, all of which are important in the control of sophisticated technologies [21].

\section{Teamwork}

Students should be able to work in teams according to instructions from the team leaders.

"In the short term, creating an enjoyable and harmonious work environment will give us teamwork" (Participant 1)

"(Teamwork refers to the) ability to communicate efficiently and work in teams." (Participant 2)

"To manage a project, one needs to work with the group."

(Participant 4)

"teamwork is important, that need in work organization"

(Participant 5)

\section{Problem-solving}

Graduates must be able to solve problems rationally and take reasonable risk in every decision.

"I see how (the applicant) analyses and generates ideas to solve a problem, how hel she speaks, how hel she manages groups, and how he/ she can assure me that he can perform all assignments."

(Participant 1)

"We also need to consider the circumstances...(for example,) if you want to use a micropile... a micropile is the best method if you want to place a pile close to a building."

(Participant 3)

"(Problem-solving imvolves) troubleshooting skills, technical skills, and diversity." (Participant 4)

"The meaning of the term is that we know (a person) has a way to solve a problem."

(Participant 5)

\section{Technicality}

Individuals with this talent are able to dominate the field, and handle the technology and machines required at work.

"Technology used to be well-incorporated into engineering engineering and technology courses. Knowledge and application are important (in this field). When I was studying civil engineering, what we learned in the classroom used to be applied in our work."

(Participant 3)

"(Problem-solving imvolves) troubleshooting skills, technical skills, diversity, proper use of machines and equipment, as well as rapid learning of skills."

\section{(Participant 4)}

"In the field of engineering, when there is any problem, the reason behind it needs to be known. (The worker) must think about how to solve the problem... for example, if hel she connects the red wire with the black, what is going to happen... if hel she connects the red wire with the blue wire, whether it will explode... With knowledge, he/ she will know the cause of the problem."

(Participant 5)

\section{Information}

Students should be well-equipped with theoretical and practical knowledge by the time they work.

"technical knowledge is important to apply in design, that is needs in doing project, from the lecture notes able to be know how to design project, that why theoritical knowledge is based of what you read or learn, but with that you can apply in your technical project and additionally, apart from the importance is you know what knowledge will you be apply to help your design" (Participant 3)

"In my view, the criteria required of a graduate is teamwork and software knowledge."

\section{(Participant 4)}

Information and Communication Technology (ICT)

Students need to be skilled in information technology (IT) - such as the usage of computers - when working.

"(Problem-solving imvolves) troubleshooting skills, technical skills, and diversity."

(Participant 4)

\section{Profession}

Students should be skilled in their professions if they want to join a specific industry.

"(Graduates) must be good in their professions and have 
International Conference on Recents Advancements in Engineering and Technology (ICRAET-18) |15th and 16th March 2019|Siddhartha Institute of Technology \& Sciences, Telangana, India.

a variety skills to become a worker in the industry."

(Participant 4)

\section{Leadership}

With leadership qualities, an inidividual will have confidence to leads the group during the implementation of a task.

"Talent needs to be developed effectively. With good talent, we will always be able to identify the abilities of others and help them. We have a team to achieve our goals, so we should influence the team members to use various abilities to lead and compete."

(Participant 1)

"When people ask me whether they a leader or dictator, I'll say both. This is what we call situational leadership, based on our talents." (Participant 3)

"A talented leader should lead a group to take on a job." (Participant 4)

“'Leader' and 'boss' are two different things. that why leadership is important to open your own company"

(Participant 5)

\section{Intelligence}

It refers to the ability to learn, listen to instructions, and perform tasks quickly.

"Intelligence concerns the ability to solve a problem faster"

(Participant 4)

"The meaning of (intelligence) the ability to something quickly without help from other people." (Participant 5)

\section{Programming}

Technical competency means the ability of an employee to perform an assignment at work [22]. In engineering, technical competency is needed to producing innovative and knowledgeable graduates as per the needs of the employers and the economy especially programming skills [23].

"Our company deals with programming, software, and technical data... like Microsoft software and analyses"

(Participant 4)

\section{Versatility}

An individual is versatile if he/ she can solve various problems at work and master more than one field.

"We need versatile staff who can control their emotions at work, which is, they do not mix personal problem with work problems. that can help them to solve the problem without knowing by employer"

(Participant 2)

"(We need workers who are) multi-skilled in software and machine handling."

(Participant 4)

\section{Work Talents}

Work talent is the strength or ability of an employee ti perform and achieve goals in a [24]. In the context of this research, talents are reviewed are based on the abilities of students to do their jobs [25]. Work talent also refers to the ability of an employee to manage work productively in an organisation in [26].

"Work talents comprise three attributes: technological abilities, skills, and ability to manage own work productively

(Participant 4)

\section{On-job Knowledge}

Individuals with on-job knowledge are able to carry out tasks at the workplace efficiently.

"Knowledge enables one to take on more tasks on the job. ”

(Participant 4)

"Knowledge is important in a company and job, but most people are not willing to and are not interested in (improving their knowledge)."

(Participant 5)

\section{Public Speaking}

Students should be able speak with good use of body language and tone.

"Jobs require talent in terms of knowledge, machineoperating, and speaking."

(Participant 4)

\section{Creative and Critical Thinking}

Individuals should be able to think out of the box and solve difficult problems at work.

"We need creativity... we need to think by ourselves

(Participant 5)

\section{CONCLUSION}

In conclusion, graduate require talents in order to be accepted for work. In order to excel, every graduate employee should have work experience before formally entering employment. Employers are highly interested in creating the best employees [27]. This study could help reduce the graduate unemployment rate by facilitating the development of talented students needed by the industry.

\section{ACKNOWLEDGMENT}

This research was supported by a scholarship from the Ministry of Higher Education (Mybrain15) and Universiti Tun Hussein Onn, Malaysia.

\section{REFERENCES}

1. Ismail, M. H. (2012). Kajian Mengenai Kebolehpasaran Siswazah di Malaysia: Tinjauan dari Perspektif Majikan. Prosiding Perkem VII, Jilid 2. 906-913.

2. Chang, R., Stern, L., Sondergaard, H., \& Hadgraft, R. (2009). Places For Learning Engineering:A Preliminary Report Of Informal Learning Spaces. Dicapai pada 1 Jun 2016 dari http:// rees2009.pbworks.com/ f/rees2009_submission_86.pdf.

3. Unit Perancangan Ekonomi (2015). Rancangan Malaysia Kesebelas (2016-2020). Percetakan Nasional Malaysia Berhad. Kuala Lumpur.

4. Hassan, N. F., Puteh, S., \& Buhari, R. (2015). Student understanding through the application of technology enabled Active Learning in practical training. ProcediaSocial and Behavioral Sciences, 204, 318-325.

5. Humburg, M., \& Velden, R. V. D., \& Verhagen, A., (2013).The Employbility of Higher Education Graduates: The Employers' Perspective. Final Report. Research Centre for Education and the Labour Market. Netherlands. European Union. ISBN 978-92-79-31236-6. DOI: $10.2766 / 54258$.

6. Langa, C., (2015). The Contribution of Transversal Competences to The Training of The Educational 
Sciences Specialist. The 6th International Conference Edu World 2014 "Education Facing Contemporary World Issues", 7th - 9th November 2014. Social and Behavioral Sciences. 1(1). 7-12.

7. Ministry of higher education Malaysia, (2015). Kementerian Pendidikan Tinggi Malaysia. (2015). Ringkasan Eksekutif Pelan Pembangunan Pendidikan Malaysia 2015-2025 (Pendidikan Tinggi). Kementerian Pendidikan Malaysia. www.moe.gov.my.

8. Husain, M. Y. \& Rasul, M. S. \& Mustapha, R. \& Malik, S. A. \& Abd Rauf, R. A. (2013). Tahap kemahiran employability pelajar kejuruteraan dari perspektif majikan. Jurnal Teknologi. 62(1). 31-39.

9. Mansor, M. \& Mat Rashid, A. (2013). Kesediaan Kerjaya Pelajar Institut Kemahiran Belia Negara. Seminar Pasca Siswazah Dalam Pendidikan (GREDUC 2013). 123-130.

10. Sanusi, A. \& Puteh, S. (2017). Research Needs: Issues and Problems of Talent Working Graduates University Programmes of Engineering and Technology. Advanced Science Letters, Volume 24, Number 11, November 2018, pp. 8051-8055(5).

11. UNESCO. (2015). United Nations Educational, Scientific and Cultural Organization. Transversal Skills in TVET: Policy Implications. Asia-Pacific Education System Review Series. Published in 2015 by the United Nations Educational, Scientific and Cultural Organization 7 , place de Fontenoy, 75352 Paris 07 SP, France and UNESCO Bangkok Office.

12. Amran, N. N., \& Ibrahim, M. \& Hassan, R., \& Ismail, K. (2016). Pendekatan Service- Learning Dalam Kursus Kemahiran Insaniah : Transformasi Positif Dalam Kalangan Perubatan UKM-UNPAD ( Sevice- Learning among UKM-UNPAD Medical Students).

13. Hassan, N. F., \& Puteh, S. (2017). A Survey of Technology Enabled Active Learning in Teaching and Learning Practices to Enhance the Quality of Engineering Students. Advanced Science Letters, 23(2), 1104-1108.

14. Madlan, L. W. \& Chua, B. S. \& Halik, M. H. \& Bahari, F. H. \& Mutang, J. A. (2015). Peningkatan Kualiti Diri Melalui Intervensi Interpersonal. Jurnal Psikologi Malaysia. 29 (2). 123-134.

15. ManpowerGroup (2012). Talent Shortage Survey. Manpower group 100 Manpower Place, Milwaukee, Wi 53212, Usa, www.manpowergroup.com. 1-36.

16. Creswell, J.W. (2012). Educational research: planning, conducting, and evaluating quantitative and qualitative research. Pearson Education. Fourth Edition.E. H. Miller, "A note on reflector arrays (Periodical style-Accepted for publication)," IEEE Trans. Antennas Propagat., to be published.

17. Braun, V. \& Clarke, V. (2006). Using Thematic Analysis in Psychology. Qualitative research in psychology 3(2): 77-101.

18. Marthalita, P. \& Kismanto, I. A., \& Kusrini, D. E., (2011). Pengukuran Bakat Berdasarkan Faktor-Faktor yang Membentuk Bakat Pada Pekerja Dengan Menggunakan Structural Equation Modeling. Undergraduate Thesis, Statistics. Institut Teknologi Sepuluh Nopember Surabaya.

19. Abdul Aziz, S. N. \& Zulkifli, N. (2015). Pengaruh Motivasi dan Gaya Pembelajaran Terhadap Pencapaian Pelajar Dalam Subjek Ekonomi Asas. International Conference On Postgraduate Research (ICPR 2015). 132-142.

20. Wu, M., Yan, H., \& Zheng, B. (2012, June). Multi-level Project Driven Computer Applied Talents Training. In 2012 IEEE 14th International Conference on High Performance Computing and Communication \& 2012 Approach In Soft Skill Course: Positive Transformation

IEEE 9th International Conference on Embedded Software and Systems (pp. 1653-1657). IEEE.

21. Kota, S. (2016, April 29). Advanced Technologies for Growth and Talent. Retrieved February 18, 2018, from http://advancedmanufac technologies-growth-talent/.

22. Lockwood, D., \& Ansari, A. (1999). Recruiting and retaining scarce information technology talent: a focus group study. Industrial Management \& Data Systems, 99(6), 251-256.

23. Abdulwahed, M., \& Hasna, N. O. (2017). Engineering and Technology, Talent for Innovation and KnowledgeBased Economies. Springer International Publishing AG.

24. Ashton, C., \& Morton, L. (2005). Managing talent for competitive advantage: Taking a systemic approach to talent management. Strategic HR review, 4(5), 28-31.

25. Clifton, D. O., \& Harter, J. K. (2003). Investing in strengths. Positive organizational scholarship: Foundations of a new discipline, 111-121.

26. Ghazali, S. Z. M. dan Ismail, A. (2013). Kaitan Antara Latihan Pengurusan Bakat dengan Prestasi Kerja dalam Sektor Perbankan Islam. Prosiding Perkem VII, Jilid I. 101-111.

27. Gallup Organization. (2001). Summary of Selection Research Item Bank. Internal Company Database.

\section{AUTHORS PROFILE}

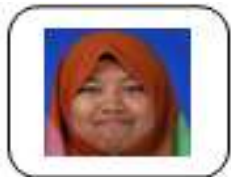

Amanina binti Muhamad Sanusi, received the B.S. degree in Electrical Engineeing from Universiti Tun Hussein Onn Malaysia in 2015 where she is currently pursuing the Ph.D. degree in Technical and Vocational Education. Her current research interests include talents and

workability in education.

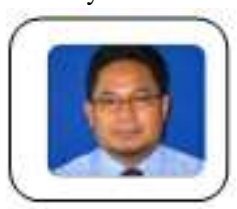

Saifullizam bin Puteh, received the B.S degree in Electrical Engineering from Universit Teknologi Malaysia in 1998 and the Ph.D. degree in Computational Intelligent in Nottingham Tren University in 2014. He is currently an Associate Professor with the Universiti Tun Hussein Onn Malaysia in Faculty Technical and Vocationa Education. His current research interests include innovation and technology in TVET, Computational Intelligent, Electronic and Electrical Engineering, Occupational Work and Competence Development, Shaping Work and Technology

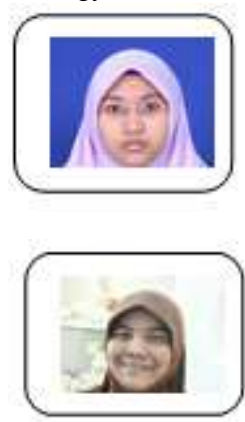

Nur Farha bte Hassan, received the B.S. degree in Electrical Engineering from Universit Tun Hussein Onn Malaysia in 2015, where she is currently pursuing the Ph.D. degree in Technical and Vocational Education. Her current research interests include Technology Enabled Active Learning.

Zaiton binti Arifin, received the Advanced Diploma in Electrical (Power) Engineering from Universiti Teknologi MARA Shah Alam in 1987. She is currently a lecture with the Politeknik Sultan Abdul Halim Mu'Adzam Shah in Electrical Engineering Department. Her current research interests include Teaching, e-Learning and lecturing in Electrical Engineering.

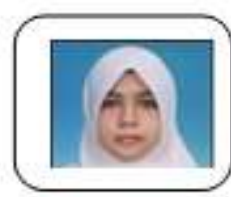

Nan Nurul Hidayah binti Megat Salleh, received the B.S. degree in Electrical Engineering from Universiti Tun Hussein Onn Malaysia in 2012, where she is currently pursuing the Ph.D. degree in Technical and Vocational Education. Her current research interests include 21st Century Skills Learning. 